\title{
Active surveillance of avian influenza viruses in Egyptian poultry, 2015
}

\author{
A.S. Kayed ${ }^{1}$, A. Kandeil ${ }^{1}$, R. El Shesheny ${ }^{1}$, M.A. Ali ${ }^{1}$ and G. Kayali ${ }^{2}$
}

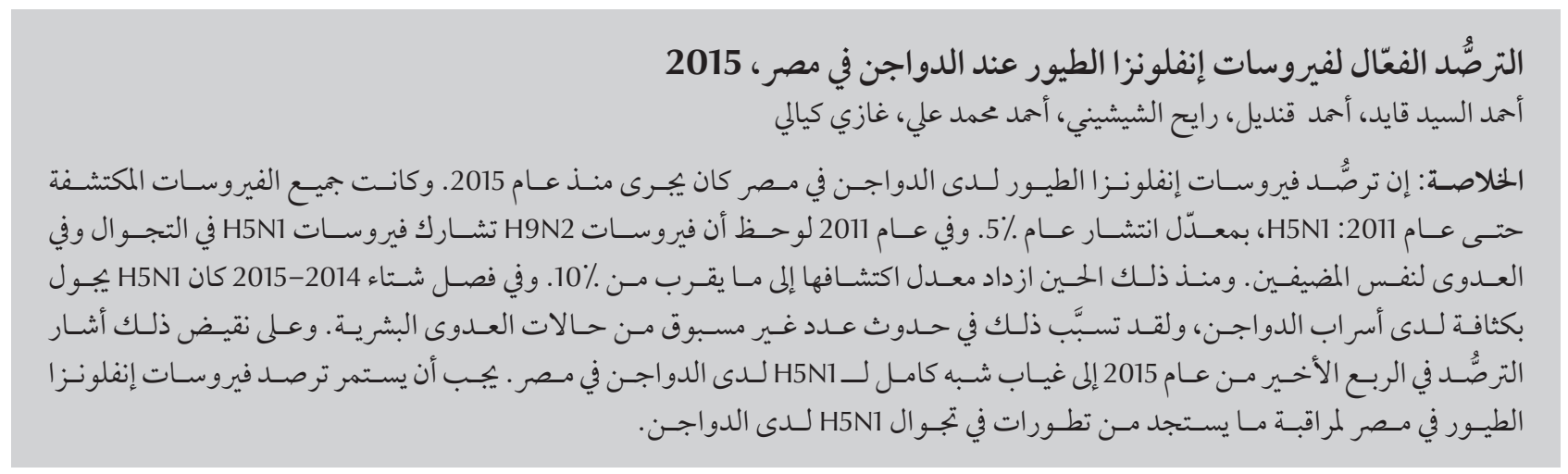

ABSTRACT Surveillance for avian influenza viruses in Egyptian poultry has been conducted since 2009. Up to 2011, all the detected viruses were H5N1, and the overall prevalence was 5\%. In 2011, H9N2 viruses were observed to be co-circulating and co-infecting the same hosts as $\mathrm{H} 5 \mathrm{~N} 1$ viruses. Since then, the detection rate has increased to around $10 \%$. In the 2014-2015 winter season, H5N1 was circulating heavily in poultry flocks and caused an unprecedented number of human infections. In contrast, surveillance in the last quarter of 2015 indicated a near absence of H5N1 in Egyptian poultry. Surveillance for avian influenza viruses must continue in Egypt to monitor further developments in H5N1 circulation in poultry.

\section{Surveillance active des virus de la grippe aviaire dans les populations de volailles égyptiennes en 2015}

RÉSUMÉ La surveillance des virus de la grippe aviaire dans les populations de volailles égyptiennes est en cours depuis 2009. Jusqu'à 2011, tous les virus détectés appartenaient au H5N1, et la prévalence générale était de $5 \%$. En 2011, on a remarqué que les virus H9N2 circulaient en même temps et co-infectaient les mêmes hôtes que les virus H5N1. Depuis, le taux de détection a augmenté pour atteindre près de $10 \%$. Pendant la saison hivernale 2014-2015, le virus H5N1 a considérablement circulé dans les élevages de volailles, entraînant un nombre d'infections sans précédent chez l'homme. À l'inverse, la surveillance au cours du dernier trimestre 2015 a constaté la quasi-absence du H5N1 dans les populations de volailles égyptiennes. La surveillance des virus de la grippe aviaire doit se poursuivre en Égypte afin de déceler les futures évolutions de la circulation du H5N1 dans les populations de volailles. 


\section{Introduction}

Since 2006, the highly pathogenic avian influenza $\mathrm{H} 5 \mathrm{~N} 1$ virus has circulated among domestic poultry in Egypt, causing massive economic losses in the poultry production sector (1). Within a few months of the first wave of $\mathrm{H} 5 \mathrm{~N} 1$ virus in 2006, the veterinary authorities in Egypt implemented a comprehensive response plan to control the spread of the virus in Egypt; this included increasing public awareness through the media, culling infected poultry, placing restrictions on the movement of live poultry, and applying biosecurity measures and emergency vaccination $(2,3)$. However, the $\mathrm{H} 5 \mathrm{~N} 1$ virus continued to circulate and it became endemic in 2008, which led to genetic drift of the surface immunogenic glycoproteins (4,5). Accordingly, the Egyptian H5N1 viruses diversified into several subclades (classical 2.2.1, 2.2.1.1, 2.2.1.1a and 2.2.1.2), of which at least two subclades co-circulated between 2008 and 2011 (6-8). The subclades of $\mathrm{H} 5 \mathrm{~N} 1$ viruses in Egypt are antigenically distinct and most vaccines used are no longer antigenically matched $(2,9)$.

Egypt reported more laboratoryconfirmed cases of human infection with avian influenza virus $\mathrm{H} 5 \mathrm{~N} 1$ to the World Health Organization (WHO) between 2003 and 2015 than any other country (346 cases), with 116 deaths, giving a case fatality rate of $33.5 \%$ (10).

Weakly pathogenic avian influenza H9N2 viruses have been isolated from chickens, turkeys and quails in Egypt (11-13). All the H9N2 isolates obtained between 2010 and 2013 were closely related to Middle Eastern H9N2 viruses $(12,13)$. Poultry infected with Egyptian H9N2 viruses showed no clinical illness, except when the infection was complicated by other pathogens (14).

Active surveillance of avian influenza viruses among poultry has been conducted in Egypt since 2009 (15). The details of the surveillance system and findings from the surveillance have been published before; we previously reported that the average infection rate was about $7.7 \%$ between 2009 and 2014 $(2,16,17)$. Here, we provide an update on the changing epizootology of avian influenza viruses in Egypt during 1 year of active surveillance in 2015.

\section{Methods}

\section{Collection of specimens}

Between 1 January 2015 and 31 December 2015, a team of veterinarians collected 2383 cloacal and 1877 oropharyngeal swab samples from commercial poultry farms, backyard flocks, abattoirs and live-bird markets. Samples were taken from convenience-selected healthy birds and from sick and dead birds from the same farms in 10 of 27 governorates in Egypt, comprising 5 Nile Delta governorates (Daqahliya, Gharbiya, Menofiya, Qalubiya and Sharqiya), 1 in mid-Egypt (Fayyoum) and 4 in Upper Egypt (Assiut, Beni Suef, Menia and Sohag). The governorates selected cover the areas where the bulk of poultry growing is done. The tip of each individual swab was placed in a collection vial containing $1 \mathrm{~mL}$ of transport medium [ $50 \%$ glycerol, $50 \%$ phosphate-buffered saline, penicillin $(2 \times 106 \mathrm{U} / \mathrm{L})$, streptomycin $(200$ $\mathrm{mg} / \mathrm{L})$ and amphotericin B (250 $\mathrm{mg} / \mathrm{L})]$. The specimens were stored on ice and transported to the laboratory with $24 \mathrm{~h}$ for processing.

\section{Virus isolation and subtyping}

After viral RNA extraction, viruses were detected by $\mathrm{M}$ gene real-time polymerase chain reaction (18). Positive samples were subtyped as $\mathrm{H} 5$, H9 or co-infection with both $\mathrm{H} 5$ and $\mathrm{H} 9$ viruses, as described previously (17).

\section{Statistical analysis}

Percentages were used to summarize data. The chi-squared test was used to analyse differences within the variables examined (sample type, governorate, species and production source). A $P$-value $<0.05$ was considered statistically significant.

\section{Results}

Of 4260 samples collected, 192 (4.5\%) were positive for influenza $A$; the prevalence was significantly higher in oropharyngeal swabs $(6.2 \%)$ than in cloacal swabs $(3.2 \%)(P<0.001)(\mathrm{Ta}-$ ble 1). Of the governorates in the Nile Delta region, Daqahliya showed the highest prevalence (10.1\%), followed by Sharqiya (5.2\%). In Upper Egypt, the highest prevalence was found in Beni Suef governorate (10.0\%) followed by Assiut (5.2\%) and Sohag (4.4\%). In the targeted species, the prevalence was highest in chickens (3.7\%), followed by ducks $(2.7 \%)$ and pigeons (0.9\%); no virus was detected in samples from turkeys. The prevalence was lowest in abattoirs (1.3\%) compared to commercial farms, backyards and markets (4.6-4.9\%).

The prevalence by month is shown in Figure 1; most positive samples were detected at the start of the year with a second peak in May. The distribution of H5N1, H9N2 and co-infected samples isolated by month are shown in Figure 2. Both H5N1 and H9N2 were detected between January and August. $\mathrm{H} 5 \mathrm{~N} 1$ virus was highly prevalent in January and August, while the prevalence of H9N2 was high in February, April and July. From October, H9N2 predominated, and there were no H5N1-positive samples except one in November. No influenza A viruses were detected in samples collected in September. 


\begin{tabular}{|c|c|c|c|}
\hline Variable & $\begin{array}{l}\text { No. (\%) of samples collected } \\
\qquad(n=4260)\end{array}$ & $\begin{array}{l}\text { No. (\%) of influenza A-positive } \\
\text { samples }\end{array}$ & $P$-value ${ }^{a}$ \\
\hline Sample type & & & $<0.001$ \\
\hline Cloacal & $2383(55.9)$ & $76(3.1)$ & \\
\hline Oropharyngeal & $1877(44.1)$ & $116(5.8)$ & \\
\hline Governorate & & & $<0.001$ \\
\hline Gharbiya & $129(4.5)$ & $0(0)$ & \\
\hline Daqahliya & $670(15.7)$ & $68(10.1)$ & \\
\hline Qalubiya & $417(9.8)$ & $10(2.4)$ & \\
\hline Menofiya & $22(0.52)$ & $0(0)$ & \\
\hline Sharqiya & 747 (17.5) & $39(5.2)$ & \\
\hline Fayyoum & 717 (16.8) & $18(2.5)$ & \\
\hline BeniSuef & $20(0.46)$ & $2(10.0)$ & \\
\hline Menia & $530(12.4)$ & $6(1.1)$ & \\
\hline Assiut & $557(13.0)$ & $29(5.2)$ & \\
\hline Sohag & $451(10.6)$ & $20(4.4)$ & \\
\hline Species & & & 0.096 \\
\hline Chickens & $3767(88.4)$ & $138(3.7)$ & \\
\hline Ducks & $292(6.9)$ & $8(2.7)$ & \\
\hline Pigeons & $110(2.6)$ & $1(0.9)$ & \\
\hline Turkeys & $91(2.1)$ & $0(0)$ & \\
\hline Production sector & & & 0.270 \\
\hline Abattoir & $154(3.6)$ & $2(1.3)$ & \\
\hline Commercial farm ${ }^{2}$ & $2671(62.7)$ & $122(4.6)$ & \\
\hline Backyard flock & 777 (18.2) & $36(4.6)$ & \\
\hline Live-bird market & $658(0.2)$ & $32(4.9)$ & \\
\hline
\end{tabular}

i P-value generated by Chi Square test 2; 2 Farms with more than 1000 birds raised for commercial purposes.

\section{Discussion}

In 2015, we detected an infection rate of $4.5 \%$, and the most commonly isolated subtype was H9N2. Most of detected H9N2 viruses were from apparently healthy poultry, which reflects the widespread prevalence of this weakly pathogenic subtype among poultry in Egypt. During our previous active surveillance, the H5N1 and H9N2 subtypes were both commonly detected, with a rate of infection between August 2009 and July 2010 of $5 \%$ (exclusively H5N1 infection), increasing to $10 \%$ (H5N1, H9N2 and co-infection) during August 2010January 2013 (17). Between February

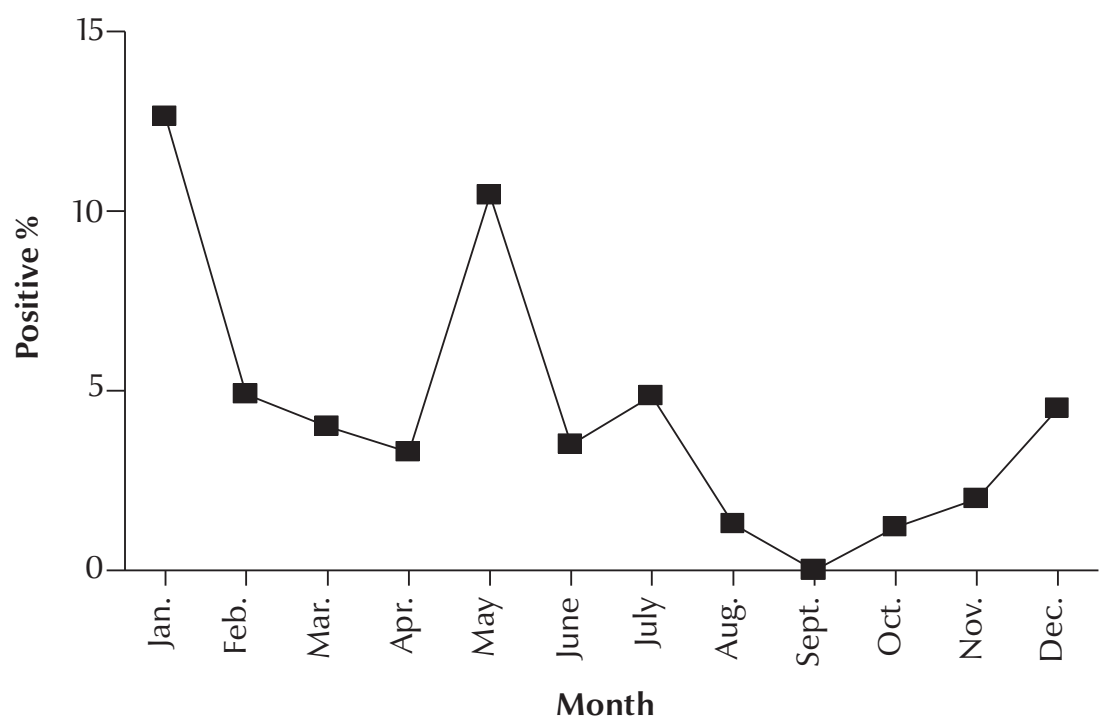

Figure 1 Percentage of samples positive for avian influenza viruses in Egyptian poultry, by month 


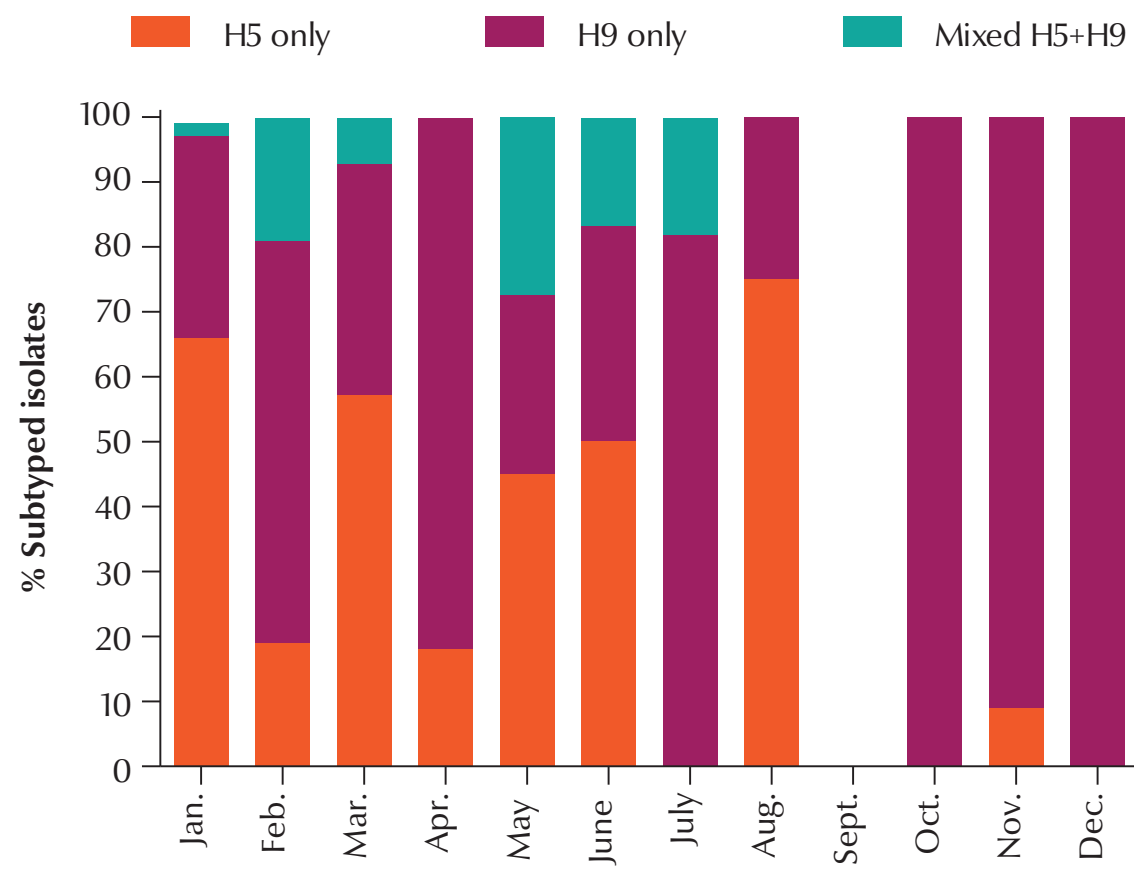

Month

Figure 2 Subtypes of influenza A virus detected in Egyptian poultry, by month

2013 and December 2014, the infection rate was about $4.7 \%$ (2).

In the last quarter of 2015 , a near absence of avian influenza subtype $\mathrm{H} 5 \mathrm{~N} 1$ was observed (in $1 / 32$ isolates), for the first time since the initiation of surveillance in 2009. This finding represents a sharp change from the 2014/15 season when many cases of human infection with $\mathrm{H} 5 \mathrm{~N} 1$ were reported. The reason for the decrease is unknown, as, to our knowledge, no interventions were introduced. Information from the field indicates that the production of eggs and subsequently chicks decreased due to heavy circulation of the velogenic Newcastle disease virus. Another possible explanation for the absence of H5N1 virus is economic. In previous years, poultry growers were allowed to purchase chicks on credit. After the events of the 2014/15 season, many growers lost their flocks and were thus unable to pay their instalments, and the credit system was stopped in 2015; thus, many growers did not raise flocks. In both scenarios, poultry density decreased, hence reducing $\mathrm{H} 5 \mathrm{~N} 1$ circulation.

It is nevertheless important to remain vigilant and continue surveillance to monitor whether the trend seen in 2015 will continue and to monitor the genetic and antigenic evolution of avian influenza in Egypt.

\section{Acknowledgements}

Funding: This work was funded by the National Institute of Allergy and Infectious Diseases, National Institutes of Health, Department of Health and Human Services, USA, under contract number HHSN272201500006C, and was supported by the American Lebanese Syrian Associated Charities (ALSAC). Funding was also received from the Science and Technology Development Fund in Egypt through contract number 5175 .

Competing interests: None declared.

\section{References}

1. Abdelwhab EM, Hassan MK, Abdel-Moneim AS, Naguib MM, Mostafa A, Hussein IT, et al. Introduction and enzootic of A/ $\mathrm{H} 5 \mathrm{~N} 1$ in Egypt: virus evolution, pathogenicity and vaccine efficacy ten years on. Infect Genet Evol 2016;40: 80-90.

2. Kayali G, Kandeil A, El-Shesheny R, Kayed AS, Maatouq AM, Cai Z, et al. Avian influenza A(H5N1) virus in Egypt. Emerg Infect Dis 2016;22:379-388.

3. Kayali G, Kandeil A, El-Shesheny R, Kayed AS, Gomaa MR, Kutkat MA, et al. Do commercial avian influenza $\mathrm{H} 5$ vaccines induce cross-reactive antibodies against contemporary H5N1 viruses in Egypt? Poult Sci 2013;92:114-118.

4. WHO, OIE, FAO. H5N1 Evolution Working Group. Continuing progress towards a unified nomenclature for the highly pathogenic $\mathrm{H} 5 \mathrm{~N} 1$ avian influenza viruses: divergence of clade 2.2 viruses. Influenza Other Respir Viruses 2009;3:59-62.

5. Abdelwhab EM, Hafez HM. Insight into alternative approaches for control of avian influenza in poultry, with emphasis on highly pathogenic H5N1. Viruses 2012;4:3179-3208. 
6. Kayali G, Webby RJ, Ducatez MF, El Shesheny RA, Kandeil AM, Govorkova EA, et al. The epidemiological and molecular aspects of influenza $\mathrm{H} 5 \mathrm{~N} 1$ viruses at the human-animal interface in Egypt. PLoS One 2011;6:e17730.

7. El-Shesheny R, Kandeil A, Bagato O, Maatouq AM, Moatasim Y, Rubrum A, et al. Molecular characterization of avian influenza $\mathrm{H} 5 \mathrm{~N} 1$ virus in Egypt and the emergence of a novel endemic subclade. J Gen Virol 2014; 95:1444-1463.

8. Arafa A, Suarez D, Kholosy SG, Hassan MK, Nasef S, Selim A, et al. Evolution of highly pathogenic avian influenza H5N1 viruses in Egypt indicating progressive adaptation. Arch Virol 2012;157:1931-1947.

9. Watanabe Y, Ibrahim MS, Ellakany HF, Kawashita N, Daidoji $\mathrm{T}$, Takagi T, et al. Antigenic analysis of highly pathogenic avian influenza virus $\mathrm{H} 5 \mathrm{~N} 1$ sublineages co-circulating in Egypt. J Gen Virol 2012;93:2215-2226.

10. Cumulative number of confirmed human cases of avian influenza $\mathrm{A}(\mathrm{H} 5 \mathrm{~N} 1)$ reported to WHO, 2003-2015. Geneva: World Health Organization; 2015 (http://www.who.int/influenza/ human_animal_interface/EN_GIP_20151214cumulativeNumb erH5N1cases.pdf?ua=1).

11. Naguib MM, Arafa AS, El-Kady MF, Selim AA, Gunalan V, Maurer-Stroh S, et al. Evolutionary trajectories and diagnostic challenges of potentially zoonotic avian influenza viruses $\mathrm{H} 5 \mathrm{~N} 1$ and H9N2 co-circulating in Egypt. Infect Genet Evol 2015;34:278-291.
12. Kandeil A, El-Shesheny R, Maatouq AM, Moatasim Y, Shehata $M M$, Bagato $\mathrm{O}$, et al. Genetic and antigenic evolution of H9N2 avian influenza viruses circulating in Egypt between 2011 and 2013. Arch Virol 2014;159:2861-2876.

13. El-Zoghby EF, Arafa AS, Hassan MK, Aly MM, Selim A, Kilany $\mathrm{WH}$, et al. Isolation of H9N2 avian influenza virus from bobwhite quail (Colinus virginianus) in Egypt. Arch Virol 2012;157: 1167-1172.

14. Kandeil A, Moatasim Y, Gomaa MR, Shehata MM, El-Shesheny $R$, Barakat $A$, et al. Generation of a reassortant avian influenza virus $\mathrm{H} 5 \mathrm{~N} 2$ vaccine strain capable of protecting chickens against infection with Egyptian $\mathrm{H} 5 \mathrm{~N} 1$ and $\mathrm{H} 9 \mathrm{~N} 2$ viruses. Vaccine 2015;34:

15. El-Zoghby EF, Aly MM, Nasef SA, Hassan MK, Arafa AS, Selim $\mathrm{AA}$, et al. Surveillance on $\mathrm{A} / \mathrm{H} 5 \mathrm{~N} 1$ virus in domestic poultry and wild birds in Egypt. Virol J 2013;10:203

16. Kayali G, El-Shesheny R, Kutkat MA, Kandeil AM, Mostafa A, Ducatez MF, et al. Continuing threat of influenza (H5N1) virus circulation in Egypt. Emerg Infect Dis 2011;17:2306-2308.

17. Kayali G, Kandeil A, El-Shesheny R, Kayed AS, Gomaa MM, Maatouq AM, et al. Active surveillance for avian influenza virus, Egypt, 2010-2012. Emerg Infect Dis 2014;20:542-551.

18. CDC realtime RTPCR protocol for detection and characterization of influenza. Atlanta, Georgia: Centers for Disease Control and Prevention; 2007 